Eur. J. Clin. Chem. Clin. Biochem.

Vol. 31, 1993, pp. 453-457

(C) 1993 Walter de Gruyter \& Co.

Berlin · New York

\title{
Establishment of Reference Ranges for Ferritin in Neonates, Infants, Children and Adolescents
}

\author{
By Gudrun Wiedemann and L. Jonetz-Mentzel \\ Klinisch-Chemisches Labor der Klinik und Poliklinik für Kindermedizin der Medizinischen Hochschule, Erfurt, \\ Germany
}

(Received March 16, 1993)

Summary: Ferritin was determined in the sera of 631 healthy neonates, infants, children and adolescents (age range 5 days to 18 years), using the IMx from Abbott Laboratories. The applied test was a microparticle enzyme immunoassay (MEIA). The proband collective was divided into 9 age groups, and each group into males and females. In accordance with the recommendations of the International Federation of Clinical Chemistry, the $95 \%$ scatter range was taken as the reference range. Only a few reference groups showed a normal Gaussian distribution. In addition to the 50th percentile, the 2.5 th and 97.5 th percentile were calculated for all reference groups, and the minimal and maximal values were also reported. Significantly different reference ranges were found for males and females in the age group 16-18 years. The U-test of Mann \& Whitney was used to test for significant differences between individual reference groups. Groups showing no significant differences were combined, and the corresponding reference ranges for serum ferritin were then calculated.

\section{Introduction}

The serum concentration of ferritin in healthy individuals and in patients with iron deficiency or iron overload is directly related to the quantity of iron stored in the reticulohistiocyte system. Whereas low serum concentrations of ferritin are always indicative of an iron deficiency, elevated concentrations can occur for a variety of reasons. Thus, although elevated concentrations often indicate an excessive iron intake, they are also caused by liver disease, chronic inflammation and malignancies (1).

In industrialized countries, iron deficiency is the commonest dietary problem. Apart from pregnant women, blood donors and haemodialysis patients, other groups particularly at risk are infants and adolescents $(2-5)$.

Determination of the serum ferritin concentration is a dependable method for the early detection of iron deficiency $(6-8)$. The first response to a decrease in the iron stores of the body is a fall in the serum concentration of ferritin. In more advanced deficiency states, the percentage saturation of the circulating ferritin and the concentration of serum iron are also decreased (1).

The aim of the investigation was:

1) to determine the reference ranges for serum ferritin in healthy neonates, infants, children and adolescents;

2) to test for significant sex differences in serum ferritin concentration within the reference groups;

3) to test for significant differences in serum ferritin concentration between the reference groups.

\section{Materials and Methods}

Ferritin was determined in the sera of 631 healthy neonates, infants, children and adolescents (age range 5 days to 18 years). In the course of routine screening for hypothyreosis venous blood was taken from 5-day-old neonates. For all other probands blood samples were taken after written consent was obtained from their parents, who were informed as to the purpose of the tests. The Ethics Commission of the Medical 
Tab. 1. Age composition of the proband collective for the determination of reference ranges of ferritin in neonates, infants, children and adolescents

\begin{tabular}{|c|c|c|}
\hline Group & Age & $\mathbf{n}$ \\
\hline $\begin{array}{l}10 \\
1 \%\end{array}$ & $\begin{array}{l}\text { 5th day } \\
5 \text { th day }\end{array}$ & $\begin{array}{l}69 \\
76\end{array}$ \\
\hline 1 & 5th day & 145 \\
\hline $\begin{array}{l}20 \\
29\end{array}$ & $\begin{array}{l}2-12 \text { months } \\
2-12 \text { months }\end{array}$ & $\begin{array}{l}12 \\
10\end{array}$ \\
\hline 2 & $2-12$ months & 22 \\
\hline $\begin{array}{l}3 \% \\
3 \%\end{array}$ & $\begin{array}{l}2-3 \text { years } \\
2-3 \text { years }\end{array}$ & $\begin{array}{l}15 \\
14\end{array}$ \\
\hline 3 & $2-3$ years & 29 \\
\hline $\begin{array}{l}4 \text { ठ } \\
4 \text { क }\end{array}$ & $\begin{array}{l}4-6 \text { years } \\
4-6 \text { years }\end{array}$ & $\begin{array}{l}37 \\
20\end{array}$ \\
\hline 4 & $4-6$ years & 57 \\
\hline $\begin{array}{l}50 \\
5 \%\end{array}$ & $\begin{array}{l}7-9 \text { years } \\
7-9 \text { years }\end{array}$ & $\begin{array}{l}37 \\
38\end{array}$ \\
\hline 5 & $7-9$ years & 75 \\
\hline $\begin{array}{l}6 \% \\
6 \%\end{array}$ & $\begin{array}{l}10-11 \text { years } \\
10-11 \text { years }\end{array}$ & $\begin{array}{l}39 \\
51\end{array}$ \\
\hline 6 & $10-11$ years & 90 \\
\hline $\begin{array}{l}70 \\
7 \%\end{array}$ & $\begin{array}{l}12-13 \text { years } \\
12-13 \text { years }\end{array}$ & $\begin{array}{l}38 \\
40\end{array}$ \\
\hline 7 & $12-13$ years & 78 \\
\hline $\begin{array}{l}8 \text { o } \\
89\end{array}$ & $\begin{array}{l}14-15 \text { years } \\
14-15 \text { years }\end{array}$ & $\begin{array}{l}31 \\
33\end{array}$ \\
\hline 8 & $14-15$ years & 64 \\
\hline $\begin{array}{l}9 \text { \% } \\
9 \text { 우 }\end{array}$ & $\begin{array}{l}16-18 \text { years } \\
16-18 \text { years }\end{array}$ & $\begin{array}{l}37 \\
34\end{array}$ \\
\hline 9 & $16-18$ years & 71 \\
\hline
\end{tabular}

School of Erfurt gave its agreement for this purpose. The age composition of the proband collective is summarized in table 1. Individuals were included or excluded according to the criteria of Witt \& Trendelenburg (9), which permit the assembly of a reliable reference sample at a justifiable expense. Only those neonates with a birthweight between 2500 and $4000 \mathrm{~g}$ and a full term gestation time between 37 and 40 weeks were admitted to the 5-day-old age group. Neonates with hyperbilirubinaemia were excluded, as well as those born to mothers with acute or chronic illnesses.

\section{Test material}

About $2 \mathrm{ml}$ of blood were taken between 08.00 and $10.00 \mathrm{am}$ from an arm or skull vein, using safety monovettes from Sarstedt, Nümbrecht. Blood samples were centrifuged immediately for $5 \mathrm{~min}$ at $3000 \mathrm{~min}^{-1}$. The serum was removed with a pipette, then frozen at $-22^{\circ} \mathrm{C}$ until analysed.

\section{Methods}

Ferritin was determined by a microparticle enzyme immunoassay, using the IMx from Abbott Laboratories. The stated test sensitivity was $1.0 \mu \mathrm{g} / \mathrm{l}$. The method was calibrated with the WHO standard $80 / 602$.

\section{Quality control}

For the control of precision from day to day, standards (from Abbott Laboratories) of low, intermediate and high concentration were included intermittently in each series. As a measure of the relative methodical error, the arithmetic mean $(\bar{x})$, standard deviation (s) and the coefficient of variation (CV) were calculated from the individual results of these control series. Precision in series was monitored once, using calibrators " $B$ " and " $E$ " of low and high concentrations from Abbott Laboratories. Again, the arithmetic mean $(\overline{\mathrm{x}})$, standard deviation (s) and coefficient of variation (CV) were calculated from the individual results.

\section{Statistical evaluation of the results}

The results were first presented as separate histograms for each age group and for each sex. The type of distribution was determined with the Kolmogorov-Smirnov test. If the resulting error probability was below the stated value of $\alpha=0.05$, the distribution was assumed to be normal. If the distribution was not normal, the 2.5th, 50th and 97.5th percentiles were determined for that reference group. In each age group, the values for ferritin were tested for significant sex differences, using the U-test of Mann \& Whitney, again using a limiting value of $\alpha=0.05$ for the error probability. In the absence of a significant sex-related difference, males and females were subsequently treated as a single group. The U-test of Mann \& Whitney was also used to test for significant differences between age groups, and all groups showing no significant difference were combined. The median value and reference range for serum ferritin were calculated for all the final combinations of reference groups. The degree of any linear relationship between age and serum ferritin concentration was determined by calculation of the correlation coefficient, $\mathrm{r}$.

\section{Results}

Ferritin was determined in the serum of 631 healthy probands ( 315 males, 316 females). Figure 1 gives an

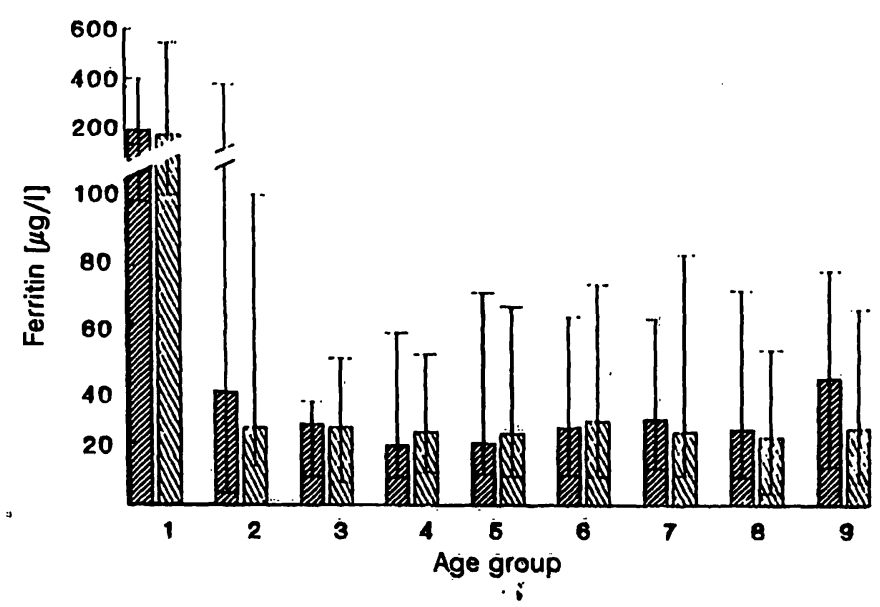

Fig. 1. 50th Percentiles and $95 \%$ intervals for the concentrations of ferritin $(\mu \mathrm{g} / \mathrm{l})$ in the serum of age groups $1-9$ (see tab. 1).

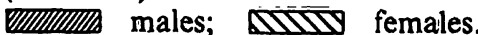


Tab. 2. Results of the U-test of Mann \& Whitney for statistically significant differences between the serum ferritin concentrations of proband groups. For two-sided significance limits and an error probability of $\alpha=0.05$, a difference is considered significant, if the calculated value for $p$ is less the 0.05 . Significant differences are shown in heavy print.

\begin{tabular}{|c|c|c|c|c|c|c|c|c|c|}
\hline & 1 & 2 & 3 & 4 & 5 & 6 & 7 & 8 & 93 \\
\hline 2 & 0.0000 & & & & & & & & \\
\hline 3 & 0.0000 & 0.0802 & & & & & & & \\
\hline 4 & 0.0000 & 0.0117 & 0.3306 & & & & & & \\
\hline 5 & 0.0000 & 0.0420 & 0.7415 & 0.4005 & & & & & \\
\hline 6 & 0.0000 & 0.2594 & 0.0590 & 0.0009 & 0.0071 & & & & \\
\hline 7 & 0.0000 & 0.2030 & 0.1392 & 0.0039 & 0.0270 & 0.6910 & & & \\
\hline 8 & 0.0000 & 0.0243 & 0.6188 & 0.5803 & 0.8113 & 0.0073 & 0.0221 & & \\
\hline 98 & 0.0000 & 0.8385 & 0.0001 & 0.0000 & 0.0000 & 0.0009 & 0.0005 & 0.0000 & \\
\hline 90 & 0.0000 & 0.1110 & 0.5625 & 0.1546 & 0.3915 & 0.2086 & 0.3098 & 0.3319 & 0.0003 \\
\hline
\end{tabular}

Tab. 3. 50th Percentile, $95 \%$ interval, minimal value and maximal value for the serum concentration of ferritin in neonates, infants, children and adolescents (values in $\mu \mathrm{g} / \mathrm{l}$ )

\begin{tabular}{|c|c|c|c|c|c|c|}
\hline Age & Sex & $\mathrm{n}$ & $\begin{array}{l}\text { Median } \\
\text { (50th percentile) }\end{array}$ & $\begin{array}{l}\text { Normal } \\
\text { (95\% scatter range) } \\
(2.5-97.5 \text { th } \\
\text { percentile) }\end{array}$ & Minimum & Maximum \\
\hline 5 days & $\delta / 9$ & 145 & 226 & $110-503$ & 85.7 & 595 \\
\hline $2-12$ months & $3 / 9$ & 22 & 31.8 & $4.01-405$ & 4.01 & 405 \\
\hline $\begin{array}{c}2-9 \text { years } \\
14-15 \text { years }\end{array}$ & $\begin{array}{l}\delta / 9 \\
0 / 9\end{array}$ & 225 & 22.2 & $9.29-58.7$ & 4.03 & 71.7 \\
\hline $\begin{array}{l}10-11 \text { years } \\
16-18 \text { years }\end{array}$ & $\begin{array}{l}\text { d/? } \\
\text { o }\end{array}$ & 203 & 25.9 & $10.1-62.9$ & 7.32 & 75.3 \\
\hline $16-18$ years & $\sigma^{*}$ & 38 & 41.8 & $12.4-78.0$ & 12.4 & 78.0 \\
\hline
\end{tabular}

overview of the results for all groups before significance testing. A significant difference between the sexes was found only in age group $9(p=0.0003)$. Tests for significant differences between all the reference groups were made, using the U-test of Mann \& Whitney (tab. 2).

Table 3 shows the new groups formed after significance testing. The median value and reference range for serum ferritin were recalculated for each new group combination.

A correlation analysis was performed for the relationship between proband age and the serum concentration of ferritin. A significant negative correlation ( $p<0.001$ ) was found between the age of the children (in months) and the concentration of serum ferritin, i.e. the ferritin concentration decreased with increasing age $(r=-0.6140)$.

\section{Quality control}

Results of the quality control are shown in table 4 . The coefficients of variation within series and between series were all less than $10 \%$.
Tab. 4. Results for the control of precision from day to day and in series

\begin{tabular}{llcccc}
\hline & Control serum & $\mathrm{n}$ & $\begin{array}{l}\overline{\mathrm{x}} \\
{[\mu \mathrm{g} / \mathrm{l}]}\end{array}$ & $\begin{array}{l}\mathrm{s} \\
{[\mu \mathrm{g} / \mathrm{l}]}\end{array}$ & $\begin{array}{l}\mathrm{CV} \\
{[\%]}\end{array}$ \\
\hline Control from & Abbott L & 12 & 20.4 & 1.10 & 5.93 \\
day to day & Abbott M & 28 & 152 & 9.68 & 6.39 \\
& Abbott H & 11 & 422 & 41.3 & 9.77 \\
\hline Control in & "B" calibrator & 23 & 10.9 & 0.24 & 2.24 \\
series & "E" calibrator & 22 & 498 & 7.77 & 1.56 \\
\hline
\end{tabular}

\section{Discussion}

There are no reports in the literature of reference ranges for serum ferritin in childhood determined with the present method. Reported reference ranges for childhood $(1,3,4,10,11)$, using other methods, are shown in table 5 .

The data shown in table 5 are not comparable with the present results, because:

1) other methods were used;

2) different age classifications were used; 
Tab. 5. Reference ranges reported in the literature for the concentration of ferritin in serum (values in $\mu \mathrm{g} / \mathrm{l}$ )

\begin{tabular}{|c|c|c|c|c|c|c|}
\hline Author & Method & & Age groups & $\begin{array}{l}\text { No. } \\
\text { of probands }\end{array}$ & $\begin{array}{l}\text { Type of distribution } \\
\text { and scatter range }\end{array}$ & Normal range \\
\hline $\begin{array}{l}\text { Saarinen } \\
\text { et al. } \\
1978 \\
\text { quoted in } \\
\text { Kaltwasser, } \\
1992 \text { (I) }\end{array}$ & No data & & $\begin{aligned} 0.5 & \text { months } \\
1 & \text { month } \\
2 & \text { months } \\
4 & \text { months } \\
6 & \text { months } \\
9 & \text { months } \\
12 & \text { months }\end{aligned}$ & No data & No data & $\begin{array}{r}90-628 \\
144-399 \\
87-430 \\
27-223 \\
19-142 \\
14-103 \\
1-99\end{array}$ \\
\hline $\begin{array}{l}\text { Ballin } \\
\text { et al. } \\
1992 \\
(3)\end{array}$ & RIA & $q$ & $16-17$ years & 222 & $\begin{array}{l}\text { No data } \\
\text { Median value } \\
\text { given } \pm 1 \mathrm{SD}\end{array}$ & $26.91 \pm 18.87$ \\
\hline $\begin{array}{l}\text { Lamparelli } \\
\text { et al. } \\
1988 \\
(4)\end{array}$ & ELISA & q & $\begin{array}{l}10.5-11.5 \text { years } \\
\text { Coloured, urban } \\
\text { Coloured, rural } \\
\text { Black, urban } \\
\text { Black, rural } \\
\text { White, urban } \\
\text { White, rural }\end{array}$ & $\begin{array}{r}83 \\
156 \\
50 \\
104 \\
72 \\
145\end{array}$ & $\begin{array}{l}\text { Normal distribution } \\
\text { after logarithmic } \\
\text { transformation } \\
\text { Median value } \\
\text { given } \pm 1 \mathrm{SD}\end{array}$ & $\begin{array}{ll}23.1 & (11.5-46.4) \\
34.4 & (21.4-55.0) \\
23.7 & (13.2-42.6) \\
37.0 & (24.0-56.9) \\
30.2 & (18.1-50.2) \\
32.3 & (20.4-51.3)\end{array}$ \\
\hline $\begin{array}{l}\text { Struckmej'er } \\
\& \text { Haid, } \\
1986 \\
(10)\end{array}$ & RIA & $\hat{\sigma}$ & $\begin{array}{l}<2 \text { weeks } \\
2-6 \text { weeks } \\
6 \text { weeks }-1 \text { year } \\
1-10 \text { years } \\
10-16 \text { years } \\
<2 \text { weeks } \\
2-6 \text { weeks } \\
6 \text { weeks }-1 \text { year } \\
1-10 \text { years } \\
10-16 \text { years }\end{array}$ & No clear data & $\begin{array}{l}\text { No normal } \\
\text { distribution } \\
\text { Median value } \\
\text { given, with } 90 \% \\
\text { scatter range } \\
\text { (5-95\% quantile) }\end{array}$ & $\begin{array}{rr}383.0 & (151.0-499.0) \\
163.5 & (49.8-359.3) \\
47.5 & (14.0-105.8) \\
59.0 & (31.0-88.0) \\
59.0 & (25.5-128.5) \\
& \\
383.0 & (151.0-499.0) \\
229.5 & (61.4-360.3) \\
43.0 & (21.2-119.6) \\
44.0 & (24.0-105.5) \\
46.0 & (26.0-127.2)\end{array}$ \\
\hline \multirow[t]{4}{*}{$\begin{array}{l}\text { Liappis \& } \\
\text { Schlebusch, } \\
1990\end{array}$} & LEIA & $\sigma / 9$ & $1-30$ days & 74 & No clear data & $\begin{array}{l}321.80 \pm 150.42 \\
299.80 \\
140.1-673.8\end{array}$ \\
\hline & & $\delta / 9$ & $1-12$ months & 34 & $\begin{array}{l}\overline{\mathrm{x}} \pm 1 \mathrm{~s} \\
\text { Median value } \\
\text { given, with } 95 \% \\
\text { scatter range }\end{array}$ & $\begin{array}{l}51.25 \pm 37.35 \\
40.35 \\
10.3-132.2\end{array}$ \\
\hline & & $\sigma$ & $1-14$ years & 86 & & $\begin{array}{l}31.90 \pm 15.31 \\
25.15 \\
14.0-72.2\end{array}$ \\
\hline & & q & $1-14$ years & 78 & & $\begin{array}{l}39.23 \pm 18.13 \\
36.90 \\
16.1-79.9\end{array}$ \\
\hline
\end{tabular}

3) the numbers of probands in each age group were not reported, or were very small;

4) data were sometimes lacking on the type of distribution of the reference values.

In the present study, 631 neonates, infants, children and adolescents (age range: 5 days to 18 full years) were used to determined the reference ranges of serum ferritin in childhood. The probands were first divided into 18 groups according to age and sex (see tab. 1).
The chosen age classification was based on the suggestions of Egger et al. (12) and the recommendations of the International Federation of Clinical Chemistry (13). The neonatal age of 5 days was chosen simply because the use of this age for other diagnostic studies (e.g. hypothyreosis screening) means that proband material is readily available. In contrast, no probands were available between the ages of 6 and 30 days. Also, the data from 2-12-month-old male and female infants have limited interpretative value, due to the small numbers of probands in these groups. 
Since the values of most reference groups did not show a normal distribution, the reference range was reported as the 2.5 th and 97.5 th percentiles, together with the median value (50th percentile) (14).

Tab. 6. Reference ranges for ferritin in the serum of neonates, infants, children and adolescents $(\mu \mathrm{g} / \mathrm{l})$

\section{Males}

Sth day

2-12 months

2-9 years

$10-13$ years

$14-15$ years

$16-18$ years

$110-503$
$4.01-405$
$2.29-58.7$
$10.1-62.9$
$9.29-58.7$
$12.4-78.9$

\section{Fernales}

5th day

2-12 months

2-9 years

$10-13$ years

$14-18$ years
The analytical method was a microparticle enzyme immunoassay (MEIA). Advantages of this method are its speed, its requirement for only a small sample volume, and the absence of radioactive isotopes.

Extraordinarily high concentrations of ferritin were found in the sera of 5-day-old neonates.

Sex differences were detected only in the $16-18$ years age group, where serum ferritin concentrations were significantly higher in males than in females.

The final group combinations and their respective reference ranges are shown in table 6.

\section{Acknowledgements}

The authors wish to thank Mrs. $R$. Biesenbach for technical assistance. We also thank Abbott Laboratories for their generous support, which made this work possible.

\section{References}

1. Kaltwasser, J. P. (1992) Ferritin. In: Labor und Diagnose, 4. Auflage (Thomas, L.) pp. 401-407, Die Medizinische Verlagsgesellschaft, Marburg.

2. American Society for Clinical Nutrition. Expert scientific working group (1985) Summary of a report on assessment of the iron nutritional status of the United States population. Am. J. Clin. Nutr. 42, 1318-1330.

3. Ballin, A., Berar, M., Rubinstein, U., Kleter, Y., Hershkovitz, A. \& Meytes, D. (1992) Iron State in Female Adolescents. Am. J. Dis. Childh. 146, 803-805.

4. Lamparelli, R. D. V., Van Der Westhuyzen, J., Steyn, N. P., Baynes, R. D., Macfarlane, B. J., Green, A. \& Bothwell, T. H. (1988) Nutritional anaemia in 11-year old schoolchildren in the western Cape. S. Afr. Med. J. 73, 473-476.

5. Hagemann, P. (1987) Ferritin bei Blutspenderinnen. Schweiz. Rundschau Med. 76, 103-107.

6. Taylor, P., Martinez-Torres, C., Leets, I., Ramirez, J., Garcia-Casal, M. N. \& Layrisse, M. (1988) Relationships among iron absorption, percent saturation of plasma transferrin and serum ferritin concentration in humans. J. Nutr. $118,1110-1115$.

7. Borel, M. J., Smith, S. M., Derr, J. \& Beard, J. I. (1991) Day-to-day variation in iron-status indices in healthy men and women. Am. J. Clin. Nutr. 54, 729-735.

8. Liappis, N., Mallmann, R. \& Schlebusch, H. (1992) Vergleich der Ferritin- und Eisen-Konzentration in Kapillarund Venenblutserum von Kindern, Jugendlichen und Erwachsenen. Klin. Päd. 204, 444-446.

9. Witt, J. \& Trendelenburg, C. (1982) Gemeinsame Studie zur Erstellung von Richtwerten klinisch-chemischer Kenngrößen im Kindesalter. J. Clin. Chem. Clin. Biochem. 20, $235-242$.

10. Struckmeyer, H. \& Haid, H. (1986) Richtwerte für das kinderärztliche Laboratorium. 1. Auflage, Die Medizinische Verlagsgesellschaft, Marburg.

11. Liappis, N. \& Schlebusch, H. (1990) Referenzwerte für die Ferritin-Konzentration im Serum von Kindern. Klin. Päd. 202, 99-102.

12. Egger, E., Dummler, W., Neymeyer, H.-G., Schwarze, H. \& Scholz, R. (1987) Vorschlag zum Arzneibuch der DDR, Diagnostische Laboratoriumsmethoden, AB (D. L.)-DDR 89. Allgemeines. Referenzbereiche. Zent.bl. Pharm. 126, $737-747$.

13. International Federation of Clinical Chemistry Scientific Committee, Clinical Section Expert Panel on Theory of Reference Values (1987) Approved recommendation (1987) on the theory of reference values. Part 2. Selection of individuals for the production of reference values. J. Clin. Chem. Clin. Biochem. 25, 639-644.

14. International Federation of Clinical Chemistry Scientific Committee, Clinical Section Expert Panel on Theory of Reference Values and International Committee for Standardisation in Haematology. Standing Committee on Reference Values (1987) Approved recommendation (1987) on the theory of reference values. Part 5. Statistical treatment of collected reference values. Determination of reference limits. J. Clin. Chem. Clin. Biochem. 25, 645-656.

Dr. med. Lars Jonetz-Mentzel

Doz. Dr. med. habil. Gudrun Wiedemann

Klinik und Poliklinik für Kindermedizin

der Medizinischen Hochschule Erfurt

Am Schwemmbach 32 a

D-99099 Erfurt

Bundesrepublik Deutschland 
